\title{
A miskolc-szentléleki pálos kolostor története és 2012. évi kutatása
}

\author{
MISKOLCZI MELINDA - SZÖRÉNYI GÁBOR ANDRÁS \\ Herman Ottó Múzeum, Régészeti Osztály \\ H-3529 Miskolc, Görgey Artúr u. 28., miskolczimelinda@hermuz.hu, szorenyi@hermuz.hu
}

Miskolczi, M.-Szörényi, G. A.: The history of the Pauline friary near Miskolc and it's archeological excavation in 2012

Abstract: The article summarizes the history of the medieval "Szentlélek" Pauline friary in Miskolc and the results of the excavation in 2012.

\section{Keywords: Dédes, friary, conservation}

A közigazgatásilag Miskolchoz tartozó, középkori nevén dédesinek is hívott szentléleki pálos kolostor a Bükk rejtekében, 710 méter magasságban található. Tanulmányunkban a pálos kolostor történetét és a 2012-ben folytatott feltárás eredményeit közöljük.

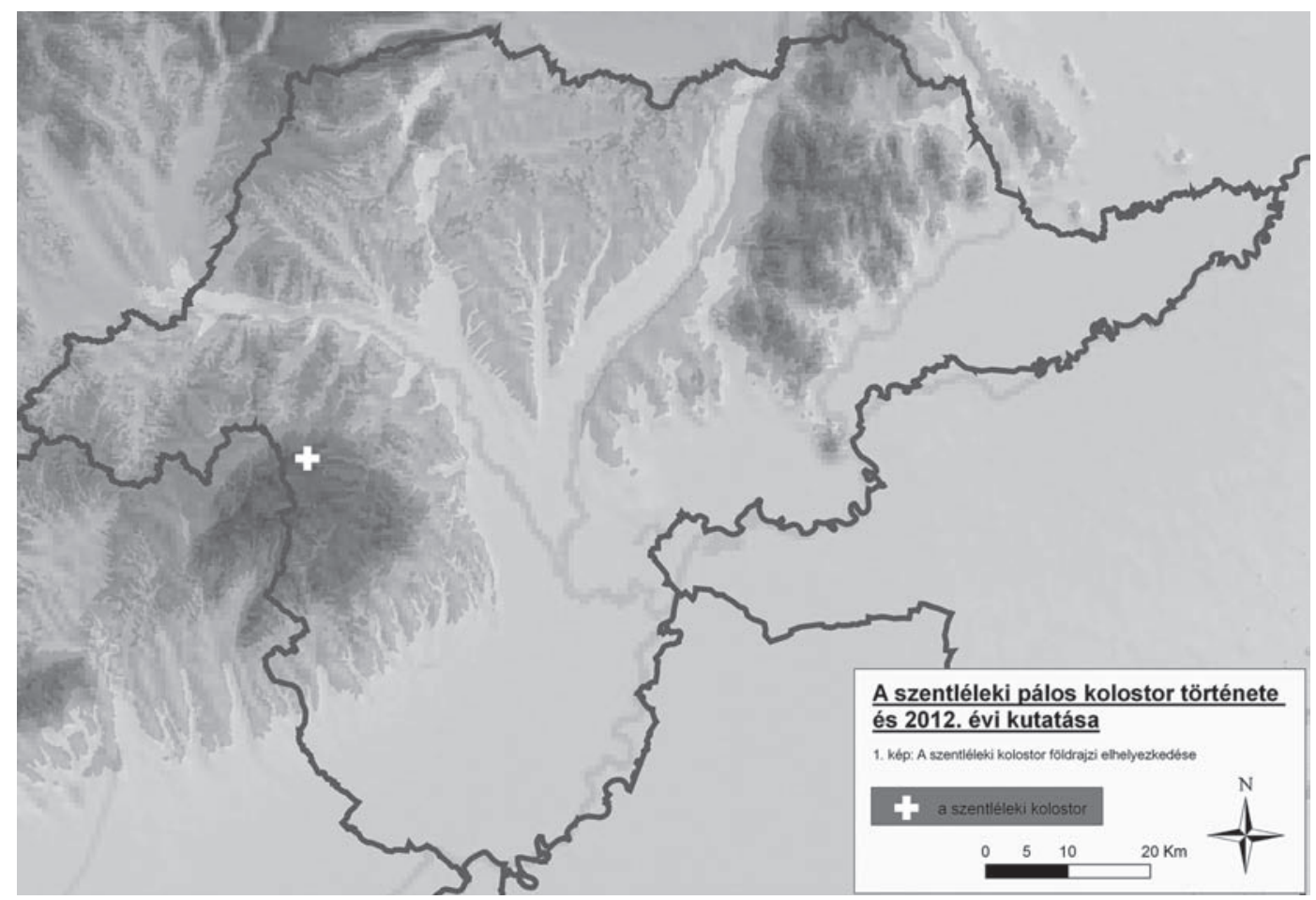

1. kép: A miskolc-szentléleki pálos kolostor elhelyezkedése (szerkesztette: Miskolczi Melinda)

\section{A szentléleki kolostor története}

A kolostorral kapcsolatos első írásos adatunk 1240-ből származik. A tardonai határjárásról szóló oklevélben - melyet Marjalaki Kiss Lajos közölt 1926-ban¹ - megemlítik, hogy a birtok határa közvetlenül a szentléleki zárda alatti völgyben fekszik, a zárdától alig néhány száz lépésnyire. Az oklevél azt is megjegyzi, hogy az egyik határjel (meta) éppen a kolostor közelében van. ${ }^{2}$ Arra a kérdésre, hogy a métául szolgáló zárdának mi

1 Marjalaki 1987. 46.

2 „...innen feljut az erdőben a Kamunusna potoka fejéhez, hol a várjobbágyoknak és M. ispánnak két határdombja van és ezen a helyen a zárda közelében (prope ad heremitas) egy vesszős alatt négy domb emelkedik, ahol elkülönül a várjobbágyoké a vár kiirtott erdejétöl..." Marjalaki 1987. 46. 
is a pontos elnevezése, illetve az ott élő közösség tagjai mely szerzetbe tartoztak, az oklevél nem szolgál bővebb felvilágosítással. A határjárás idején itt élő remetéket azonban még nem tarthatjuk pálosoknak, hiszen az egyetlen, magyar alapítású szerzetesrend első közösségét a rendi hagyomány szerint Boldog Özséb 1245-ben fogta össze. Mindazonáltal a Borsod-Abaúj-Zemplén megyében található, későbbi pálos kolostorok közül - az újhelyi kolostor mellett ${ }^{3}$ - ez a remeteközösség az egyik legkorábbi, melyről írásos emlékkel rendelkezünk.

A szentléleki pálos közösség első, oklevéllel adatolható említése 1312-ből származik. ${ }^{4}$ Ekkor az Ákos nembeli Ernye bán fia, István adományozott földterületeket a dédesi kolostornak. Ennek az oklevélnek alapján mely adományozásról és nem pedig alapításról szól (!) - is joggal feltételezhetjük, hogy a szentléleki kolostor már rendelkezett a 14. század elején korábbi előzménnyel. Ezt az 1240-es határjárásban említett kolostor jelenthette. A 13. század közepén itt élt közösség épületeiről, azok kivitelezéséről azonban nem rendelkezünk információval.

István maga is országos méltóságot viselt, előbb a királyné tárnokmestere, később országbíró, majd 13011310 között nádor volt. Nagyvonalúan támogatta a formálódó pálos rendet. 1304-ben ő alapította a diósgyőri közösség Corpus Christi titulusú templomát és a hozzá tartozó rendházat is. A két pálos kolostor támogatásának közel egyidejú volta, valamint földrajzi fekvésük felveti a kérdést, hogy miért látta szükségesnek István nádor két közösség létrehozását is birtokán? A 14. század elején István nádor kiterjedt birtokokkal rendelkezett környékünkön. Diósgyőri központja mellett - melyen megkezdte új udvarházának, és a későbbi diósgyőri várnak építését - ő birtokolta a dédesi várat is. A szentléleki kolostor pontosan a Diósgyőr - Dédes közötti út felénél helyezkedik el, kb. 8 kilométer távolságra mindkét helytől. Ennek megfelelően a kolostor kiváló testi és lelki pihenőhelyet jelentett a Dédes - Diósgyőr útvonalon.

A pálos rendház helyének kiválasztásában - azon túl, hogy már volt itt egy korábbi, ismeretlen eredetű közösség - egy másik szempont is dominálhatott. Szentlélek környezetében napjainkban is erdőterületek találhatóak, hasonlóan a középkori állapotokhoz. Ismert, hogy a nagy királyi vadászatok alkalmával az egész udvar felkerekedett, $\mathrm{s}$ a nádor vadászatai során sem lehetett ez másként. A kolostor ebben az esetben is pihenőhelyként szolgálhatott. Kálmán király első törvényének 68. fejezete azonban tiltotta a szentségek kiszolgáltatását a vadászatokon:

„....Misét mondani csak felszentelt helyen szabad. Hanem, ha valami szükség azt kivánná, máshol és akkor is sátor alatt vagy más tiszta helyen mondják, de azt is csak úton, utazás közben, nem vadászaton és soha nem kézi oltár nélkül..."

Így feltételezhetően egy-egy nagyobb vadászatot követően a szentléleki kolostorban pihentek meg és mondtak misét. ${ }^{5}$

A dédesi kolostor a középkor folyamán Diósgyőrrel és Felnémettel egy gazdasági közösségbe, ún. vicariába tartozott. ${ }^{6}$ A szentléleki barátok több ízben $\left(1313,1315^{7}, 1406^{8}\right)$ a diósgyőri kolostorral közösen kaptak adományokat. Donátorai között szerepel a 14-15. században a királyi család is. Nagy Lajos király, Erzsébet királyné, Mária királynő és Luxemburgi Zsigmond bőkezű adományokat tett mindkét kolostor számára. 1459-ben Mátyás királytól kaptak a dédesi szerzetesek nagyvonalú adományt. A király ekkor 200 forint értékű sót utalt ki számukra a széki sóbányákból. ${ }^{9}$ Szentléleknek a vicariában elfoglalt pozíciójára utal az a közvetett adat is, mely szerint annak romjait és környezetét 1737-ben visszaszolgáltatták a diósgyőri kolostornak.

A szentléleki kolostorról - a diósgyőrivel ellentétben - csekély számú okleveles említés maradt fenn. A dédesi pálos közösség életében az első válság 1320 körül következhetett be. Ekkor Debreczeni Dózsa elfoglalta Diósgyőrt és Dédest is. ${ }^{10}$ Ugyan a kolostor feldúlásáról ekkor nem esik szó, mindenesetre az átvonuló hadak ismeretlen mértékú pusztítást végezhettek itt. Erre utalhat az is, hogy az 1346-ban adományt tevő Poha Benedeket a kolostor építőjeként említi a korábbi kutatás. Tudjuk, hogy a kolostor ekkoriban már állt, tehát Benedeket nem tekinthetjük az alapítónak. A ránk maradt oklevél szerint ő egy, a Vadnán áló malmot adományozott a dédesi barátoknak. Benedek adományának része lehetett abban, hogy az esetleg sérült kolostor helyreállítása megtörténhetett. Amennyiben Szentléleket a Debreczeni Dózsa-féle harcok során nem érte kár, akkor feltételezésünk szerint a malomból befolyó pénz is hozzájárulhatott a kolostor átépítéséhez, kibővítéséhez. A 15. század folyamán Szentlélek több ízben is kapott kisebb-nagyobb adományokat mind polgároktól, mind förangúaktól.

1526-ban az I. Ferdinánd szolgálatában álló Serédy Gáspár csapataival - megyénk más kolostoraihoz hasonlóan - feldúlta a diósgyőri kolostort, mert a pálos barátokat a Szapolyai-párt tagjainak vélte. Az írásos források alapján arról nincs információnk, hogy Szentléleket ekkor támadás érte, ennek tényét azonban nem lehet

3 Az újhelyi kolostorhoz köthető első írásos említés 1221-ből származik. Lásd Joó 1972. 146.

4 1312; DL 1669.

5 Lovász 2004. 51-52.

6 Hervay 1984. 168.

7 1315; DL 1669.

8 1406; DL 10447.

9 F. Romhányi 2007. 342.

10 Lovász 2004. 82. 
kizárni. 1540-ben Balassa Zsigmond emberei lerombolták a pálosok szentléleki kolostorát, mert a barátok panaszt tettek a Balassák önkényeskedései ellen. ${ }^{11}$ A kolostor 1550 körül teljesen elnéptelenedett. 1628-ban Diósgyőrhöz hasonlóan területét elzálogosították, hogy Bécsben egy új pálos rendháznak telket tudjanak venni. ${ }^{12}$ Utolsó említése 1737-ből származik, amikor a romot visszaszolgáltatták a diósgyőri pálosoknak. ${ }^{3}$ Szentléleket - több más rendházhoz hasonlóan - soha nem építették újjá.

A kolostor romjaira a 19. század közepén figyeltek fel ismét. 1856-ban Vachot Imre a Budapesti Visszhang hasábjain jelentetett meg egy rövid leírást Szentlélekről, melyhez rajzot is mellékelt. 1860-ban a Vasárnapi Újság közölt hasonló cikket ismeretlen szerző tollából. ${ }^{14}$

\section{A pálos kolostor kutatása}

A Bükk-hegység mélyén megbúvó kolostor és templomának kutatása nem új keletú történet, az 1900-as években több, különböző jellegű feltárást is végeztek itt.

A kolostor legkorábbi kutatói Krompecher László és Benedek Frigyes voltak az 1930-as években. 1942-ben dr. Szabó Ferenc írta le a kolostort, és készítette el a templom első felmérését. ${ }^{15} \mathrm{~A}$ felmérési rajzhoz mellékelt pár soros szöveg alapján ekkorra a templom ablakai mind beomlottak, a kolostorrész és a sekrestye azonban még jó állapotban volt. Sajnálatos módon ezen épületrészek felmérését dr. Szabó Ferenc nem végezte el, így nincs pontos képünk azok 1940-es évekbeli helyzetéről.

1954-ben Sódor Alajos építészmérnök vezetésével folytak Szentléleken műemléki kutatások, ahol mind a templom, mind pedig a kolostor területét vizsgálták. A kutatás során ekkor a felszínen is látható falak alaprajzi felmérésén túl rétegtani megfigyeléseket nem végeztek (2. kép). A Sódor-féle felmérések előzményének a Múzeumok és Múemlékek Országos Központjának nagyszabású terve tekinthető, melyben a kolostor környezetének revitalizását tűzték ki célul. Szentléleken a "dolgozó nép" számára kialakítandó hatalmas üdülőt álmodtak meg, melynek épülettömbjét összekötötték volna a rekonstruált kolostoregyüttessel. Szerencsés módon e tervek a későbbiekben nem kerültek megvalósításra (3. kép).

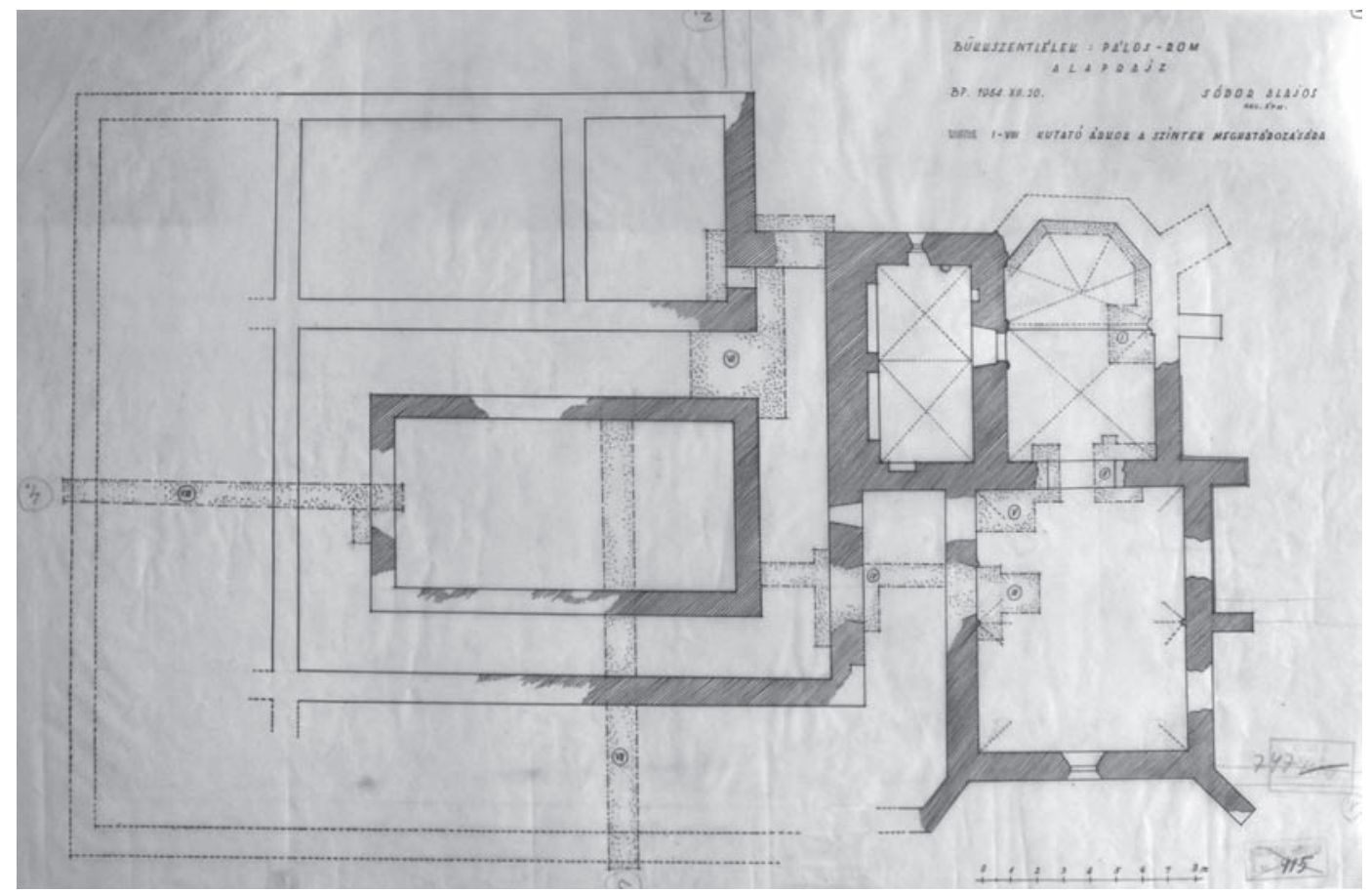

2. kép: Az 1954-ben zajlott Sódor-féle kutatás alaprajza (Forster Gyula Nemzeti Örökséggazdálkodási és Szolgáltatási Központ Müemléki tervtár, 747.)

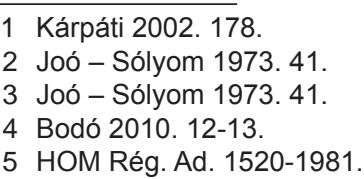




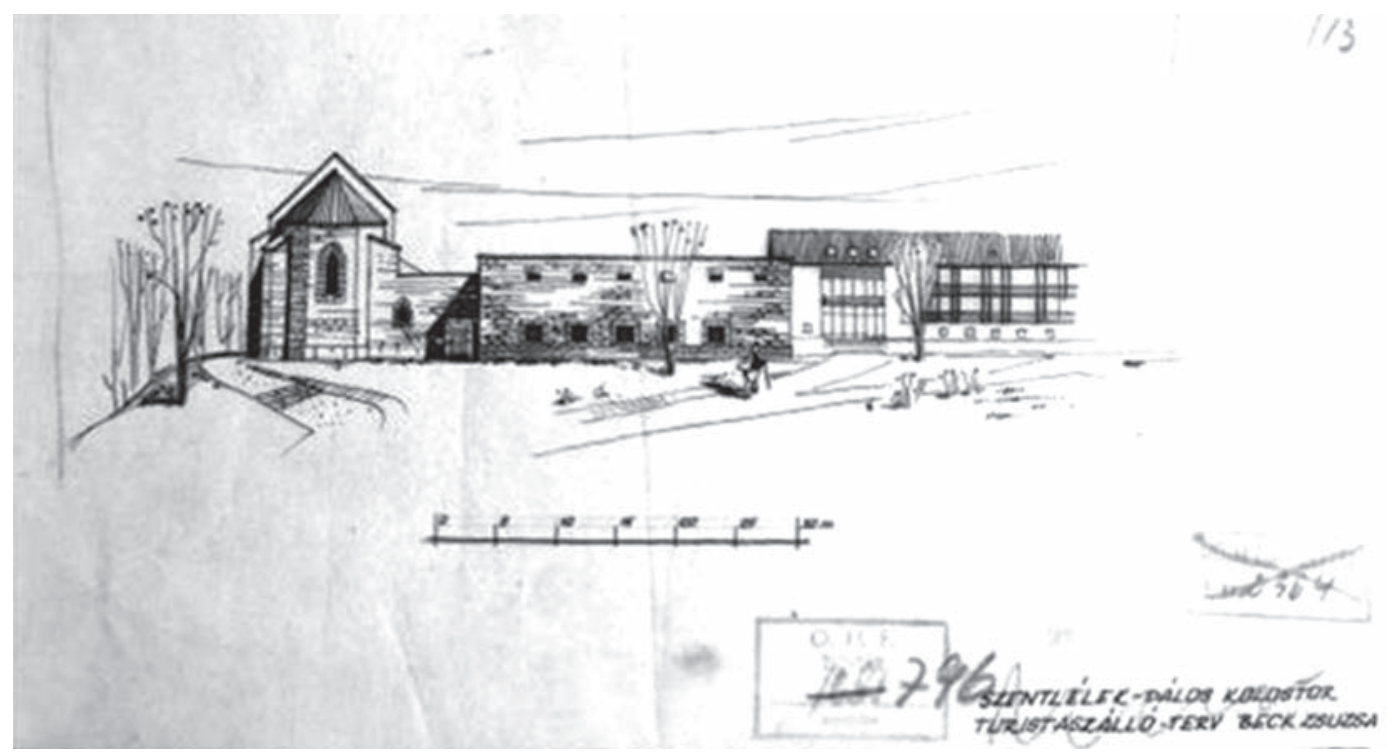

3. kép: Szentlélek - Pálos kolostor turistaszálló terv (Beck Zsuzsa) (Forster Gyula Nemzeti Örökséggazdálkodási és Szolgáltatási Központ Müemléki tervtár, 796.)

1960-ban újabb feltárás történt Szentléleken, ezúttal azonban illegális módon. A Herman Ottó Menedékház gondnoka telefonon jelentette, hogy a budapesti M. Ü. M. 1. és 13. Iparitanuló Intézet tanulói és két tanáruk "kutat" a templomban. Tevékenységüket Komáromy József szüntette be, aki a templomhajóban talált sírok leletmentését végezte el. ${ }^{16}$

1974-ben indult meg a kolostor régészeti kutatása. Ebben az évben Czeglédy llona folytatott ásatásokat túlnyomó többséggel a templom területén. Kutatása nyomán Ferenczy Károly vezetésével megtörtént annak ma is látható műemléki konzerválása és bemutatása. Munkájuk alkalmával kitisztították a kolostornégyszöget is, a látható falakat szárazon rakott kőfallal emelték ki (4. kép). Az azóta eltelt időben a kolostor területén újabb feltárások nem zajlottak, a romok elfeledve várták sorsukat.

A vadregényes, de jól megközelíthető és magas falakkal büszkélkedő templomrom Miskolc környékének egyik legjelentősebb, és a túrázók körében népszerű műemléke. Ennek köszönhetően viszonylag rendezett a környezete. A templom mellett lévő, kevésbé látványos kolostornégyszög a Czeglédy-féle feltárások óta azonban méltatlan állapotba került. Az itt üzemelő turistaház a romok területének egy részét elegyengette, azon murvával fedett rendezvényteret alakított ki. A planírozás során a mélyedéseket szeméttel töltötték fel, az északnyugati oldalon pedig egy aszfaltozott parkolót is kialakítottak. A szabadon maradt romokat az erdő kezdte visszahódítani, területén növények nőttek és megindult a humuszosodás folyamata.

Az elmúlt években sajnálatos módon a templom épületében is jelentős károk keletkeztek. Szétnyílt a diadalív boltíve, amelyet évek óta egy ideiglenes dúcolattal tartanak helyén. A kolostor és a templom területére „A műemléki helyreállításig belépni tilos" feliratú táblákat helyeztek ki, melyek már jó néhány éve állnak ott, miközben a konzerválásról nem született döntés.

A szentléleki kolostor méltatlan állapotának ügyét egy miskolci önkéntesekből álló csoport, a Csatárlánc karolta fel 2011-ben. Céljuk az, hogy a templom területén a balesetveszélyt megszüntessék a diadalív pilléreinek és boltozatának helyreállításával. Munkájukba a miskolci Herman Ottó Tudományos Egyesületet is bevonták. A kezdeményezést több vállalkozó is tá-

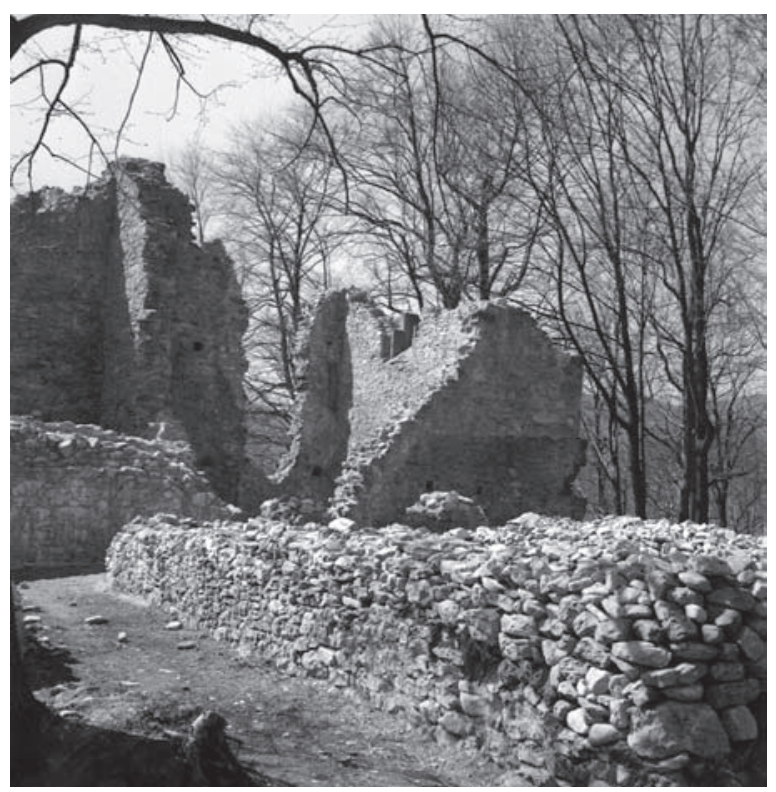

4. kép: A kolostornégyszög 1977-ben (HOM Fotó- és negatívtár, Ltsz.: 34.198.)

16 HOM Rég. Ad. 574-1968. 
mogatta 2012-ben: egy kivitelező cég ingyen biztosította a szükséges szakmunkát, a gyártó a habarcsanyagot, többen a kőanyag szállításában segédkeztek, miskolci építőipari szakiskolák pedig a tanulóknak szükséges nyári gyakorlat gyanánt elfogadták a kolostornál folytatott munkát. A Csatárlánc ennek a kezdeményezésnek a keretein belül kereste meg a Herman Ottó Múzeumot a kolostornégyszög revitalizásának tervével (5. kép). Így kezdte meg Múzeumunk Szentléleken a feltárást 2012-ben. Munkánkat miskolci középiskolások is segítették, hangsúlyozandó, hogy tanév közben (6. kép).

Kutatásunk egyik célja voltaképpen egy terület rekultiváció volt, melyet alaprajz hitelesítő és szondázó jellegű ásatás egészített ki. Ennek során szintsüllyesztést végeztünk a kolostornégyszög kb. 50\%-án, eltávolítva a növényzetet és az erdei humuszt a legfelső régészeti réteg tetejéig. Ezt követóen kutatóárkokkal szondáztuk

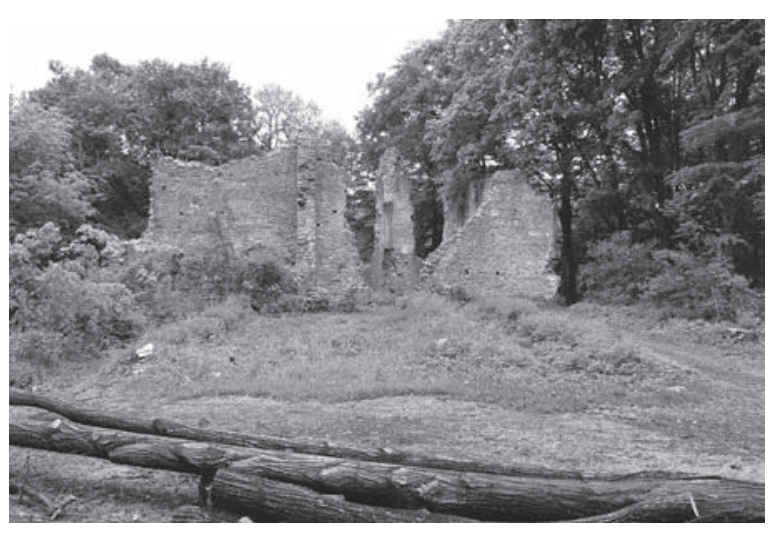

5. kép: A kolostornégyszög állapota a 2012. évi ásatás megkezdése előtt (fotó: Szörényi Gábor András)

meg a kolostornégyszöget, valamint megvizsgáltuk a parkolóval és rendezvénytérrel fedett kolostorrész kiterjedését és állapotát.

A turistaház 1930-as években folytatott átépítése során ez utóbbi területen helyezték el a vizesblokkot, melyet csak az 1960-as, 1970-es években bontottak el. A tereprendezés során szeméttel töltötték fel a területet, melynek nagyszámú tárgyi emlékét pezsgős- és borosüvegeket, kávés és tejeszacskókat, konzervdobozokat - a feltárás során megtaláltuk. A szemétréteg eltávolítása után került elő a törtkőből rakott vizesblokk alapozása, melyet a kőanyag azonossága alapján a kolostor köveiből emeltek. Ez alatt rábukkantunk a kolostor északnyugati külső falára is, így bebizonyosodott, hogy a parkoló valóban ráfedett a középkori romokra.

A jelenleg is szabadon álló kolostornégyszögben a korábbi kutatások alkalmával csupán a legfelső járószintig mélyültek le. Jelen kutatásunk során igyekeztünk a kolostornégyszög területén teljes rétegtani keresztmetszetet nyerni. A rétegek átvágásával egy összetett, többrétegű lelőhely bontakozott ki. A mintegy néhány tíz négyzetméter összterületű kutatóárkokban több mint 50 stratigráfiai egységet különítettünk el, melyekből nagyszámú leletanyag is előkerült (7-8. kép).

$\mathrm{Az}$ új- és modernkori rétegek viszonylag vékonyan fedték az intakt középkori egységeket. Ennek oka az, hogy a rommezőt egyrészt a korábbi ásatások alkalmával, másrészt a turistaház üzemeltetői többször kitakarították. Az általunk eltávolított humuszos felszín alatt, sekély mélységben jelentkeztek a kolostor pusztulási szintjei, melyeket elsősorban a

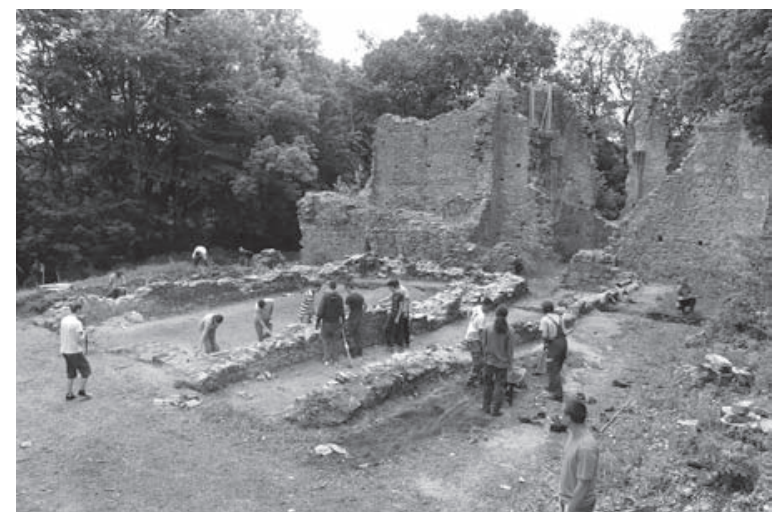

6. kép: Miskolci középiskolások segédkeznek a feltárási munkálatokban (fotó: Szörényi Gábor András)

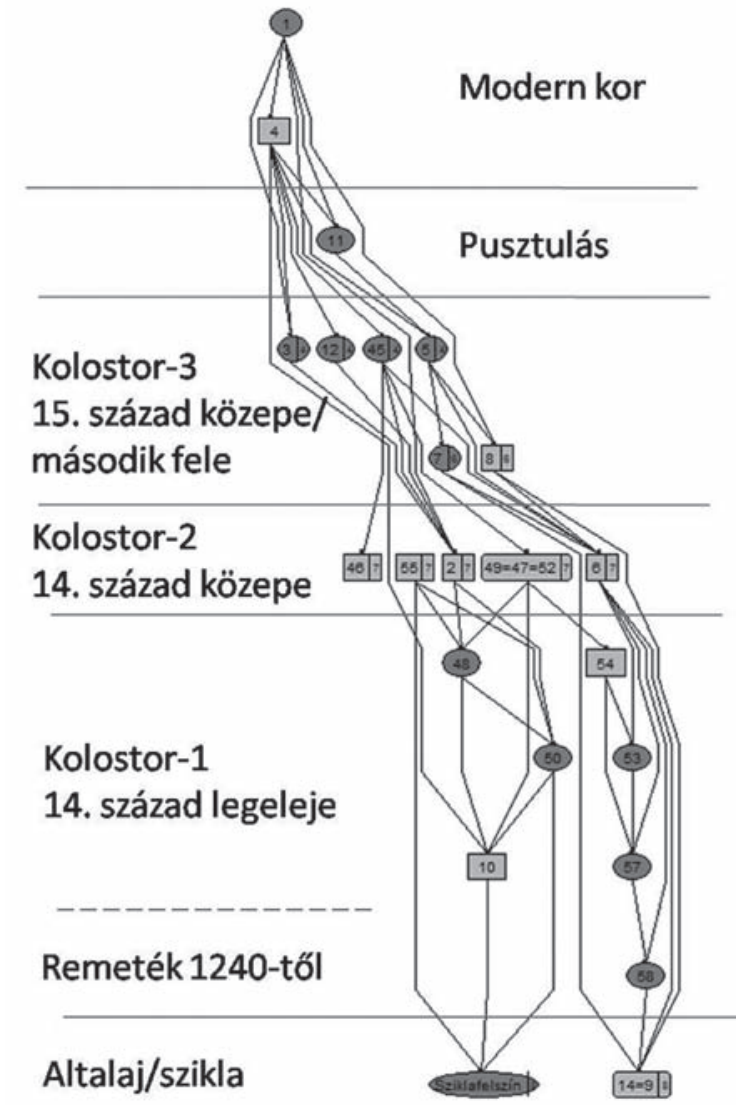

7. kép: A 2012. év kutatási eredményeinek ábrázolása Harris-mátrixon (szerkesztette: Miskolczi Melinda, Szörényi Gábor András) 
kerengőudvarban sikerült azonosítani. Itt két, szemétben roppant gazdag réteg húzódott egymás felett. A felső rétegben csak 16. századi leletanyagot, míg az alatta elhelyezkedőben 15-16. századi leleteket találtunk. Ez utóbbihoz nagy mennyiségü zsindelyszög is köthető. $E$ két szemétréteget vagy az 1540-es Balassa-féle pusztításhoz, vagy az 1526-os Serédy-féle feltételezett rongáláshoz köthetjük. Mivel e két pusztulási réteg az udvarban közvetlenül a természetes, agyagos sziklafelszínen feküdt, egyértelmű, hogy amíg rendszeres élet volt a kolostorban, addig a kerengőudvart folyamatosan tisztították.

A kolostor építési periódusait a nyugati szárnyban nyitott két árok alapján összegezhetjük. Az igen vékony, modern felszínt eltávolítva megfogható volt az utolsó periódus járószintje, melyet Sódor Alajosék is megtaláltak 1954-ben. Az általunk nyitott két szonda tanúsága szerint a kétosztatú traktus egyik részét téglával, míg a másikat csupán ledöngölt agyaggal burkolták (9. kép). A felület átvágása alapján e két burkolatot a 15. század derekán, második felében készíthették.

A kolostor - eddigi kutatásaink eredményei alapján - ebben az időszakban érte el legnagyobb kiterjedését mind nyugati, mind keleti irányban. $E$ késő középkori rétegek átvágását követően, ezek alatt dokumentáltuk egy kisebb alapterületű kolostor nyomait. Ennek a korábbi rendháznak a kb. 1 méterrel beljebb futó falait visszabontva találtuk meg, melyeket a már említett 15. századi járószintek is fedtek. A korábbi és kisebb alapterületű épület falához egyszerü, letaposott, agyagos járószintek kapcsolódtak, melyekben

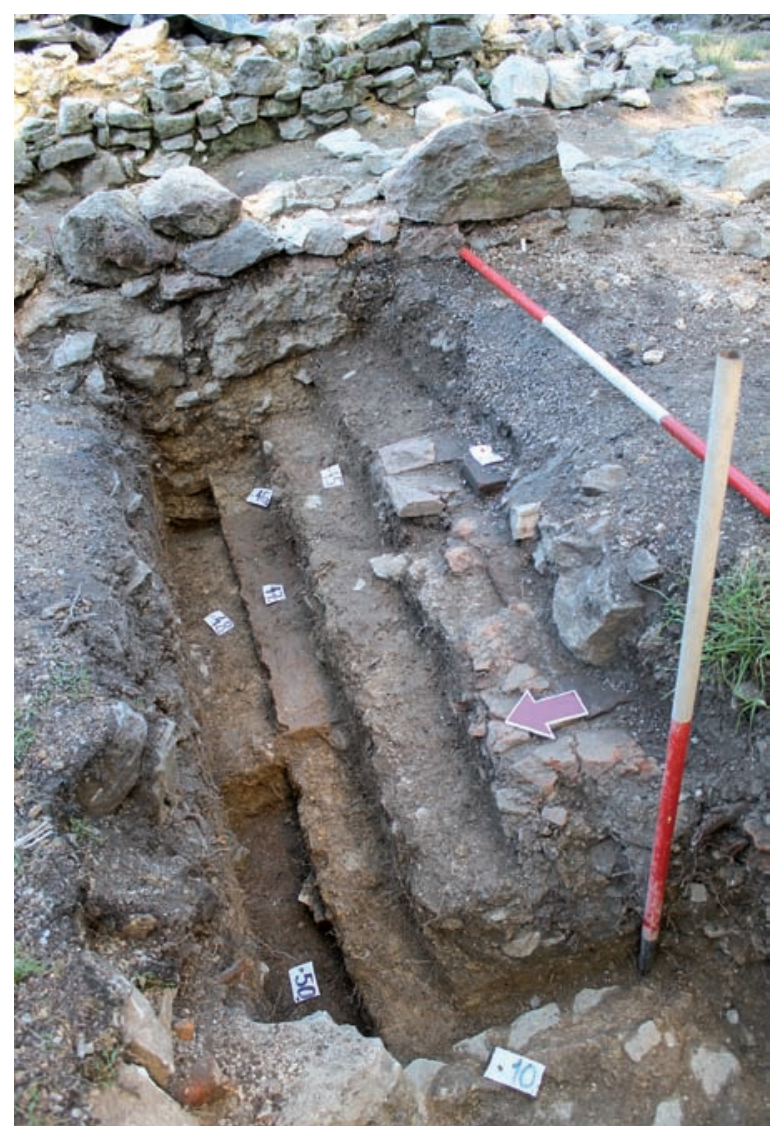

8. kép: A kibontott rétegek rendje az 1. kutatóárok nyugati felében (fotó: Szörényi Gábor András) 14. századi leletanyagot találtunk.

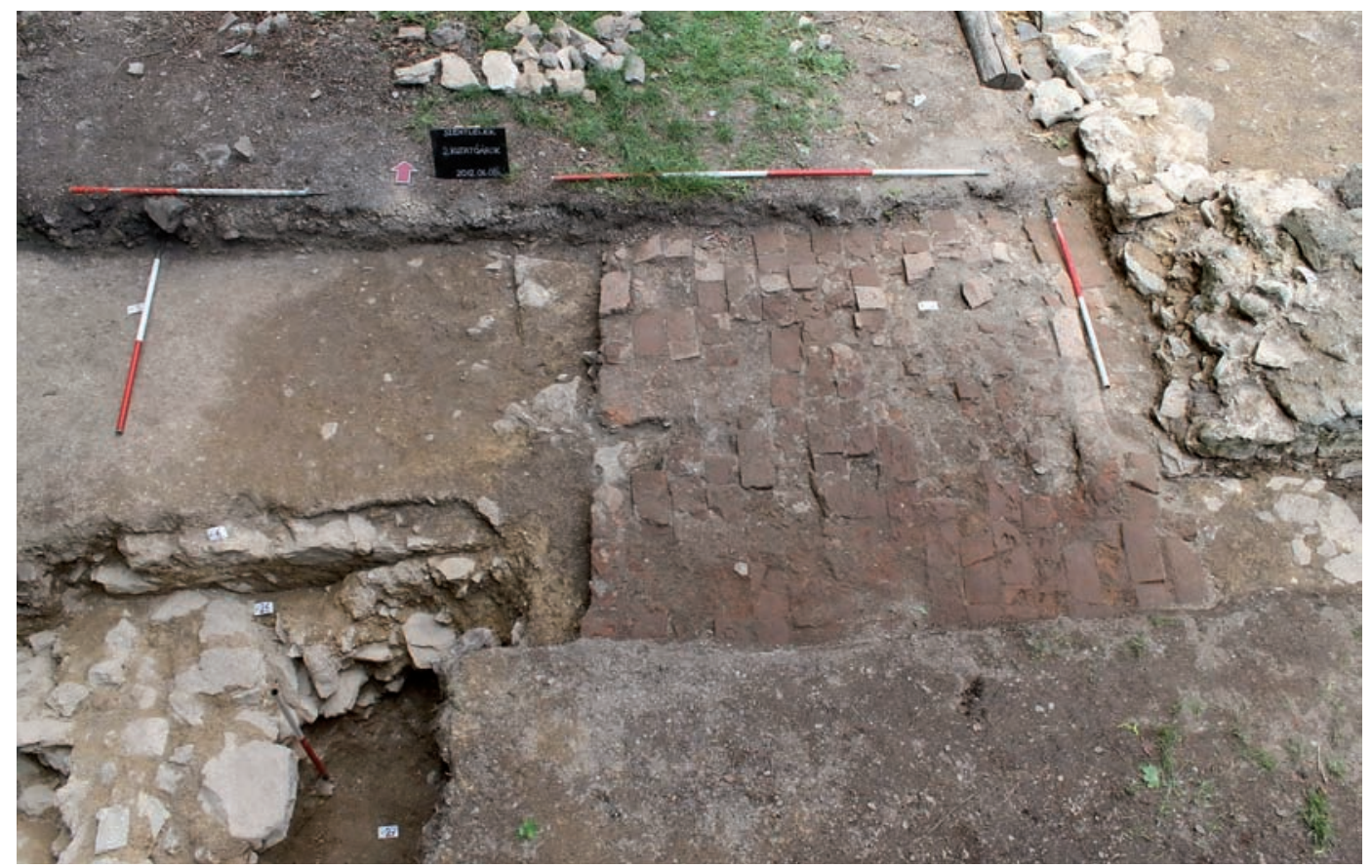

9. kép: A feltárás során kibontott kétosztatú traktus padlója (fotó: Szörényi Gábor András) 
A kutatóárokban tovább haladva, a 14. századi réteg bontása során egy harmadik, szintén visszabontott falat találtunk, mely a 14. századi faltól beljebb, a kerengőudvar felé került elő. Az ehhez a falhoz kapcsolható rétegek főleg 13. századi és kevés 14. századi leletet rejtettek. E három, egymástól jól elkülöníthető építési periódust megkísérelhetjük összekötni a kolostor történeti adataival. A pálos rendház első fázisát annak 14. század eleji alapításához és István nádor bőkezű adományaihoz köthetjük. A bővítéssel járó átépítést a 14. század közepén és végén kapott, nagyobb adományokból befolyó pénzösszegek tették lehetóvé. A kolostor utolsó átépítését a 15. században juttatott javadalmak biztosították.

Megjegyzendő, hogy mindegyik átépítési rétegben találtunk Árpád-kori anyagot, amit természetesen a legnagyobb mennyiségben a legkorábbi építéshez kapcsolódó szintekben azonosítottunk. A korai leletanyag nagy számát az 1240-es határjárás alkalmával említett remete közösséghez kapcsolhatjuk. Feltételezésünk szerint az ismeretlen eredetű közösség fából készült épületekben élhetett itt az első kőkolostor megépítéséig. A 14. századi építkezések alkalmával végzett planírozások során kerültek a korábbi közösség nyomai a különböző rétegekbe.

Bemutatott kutatásunk másik célja a kolostornégyszög revitalizálása és a feltárt falak műemléki helyreállitása volt. Ennek során elvégeztük a kibontott felszín légifotózását, melynek több száz felvételét geodéziailag bemért illesztőpontok segítségével georeferáltuk, majd az eredményről méretarányos ortofotót készítettünk (10. kép).

Ugyancsak elvégeztük a falak függőleges síkjának

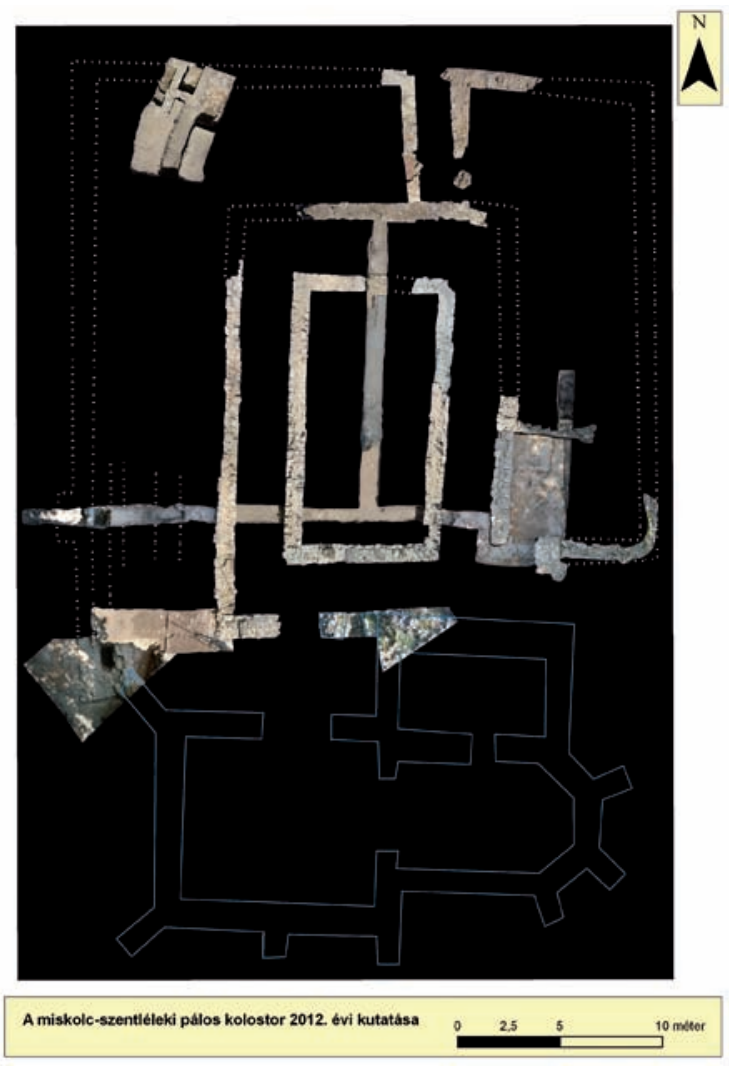

10. kép: A kolostornégyszög kutatásáról készített ortofotó (HOM Régészeti Adattár) fotózását $1 \times 1$ méteres felületekben, így a konzerválás megkezdése előtt minden frissen kibontott falat teljes körűen dokumentáltunk. Ezen munkák elvégzését a feltárást követő műemléki konzerválás tette szükségessé. Az ásatás befejezését követően a kerengőudvar és a kerengőfolyosó falainak állagvédelme megtörtént.

A templomban fennáló balesetveszély elhárítása, a diadalív pilléreinek és a boltozat helyreállításának munkálatai - az anyagi források szűkös volta miatt - várhatóan 2013 folyamán történnek meg.

A tanulmányunkban felvázolt adatok kutatásunk első évének eredményeit tükrözik. Bízunk benne, hogy a jövőben folytatni kívánt feltárások tovább árnyalják majd a szentléleki kolostorról eddig megszerzett ismereteinket.

\section{Összefoglalás}

A szentléleki - középkori nevén dédesi - pálos kolostort a 14. század elején létesítették az írott források alapján. Egy korábbi oklevélben szereplő adat alapján azonban joggal feltételezhetjük, hogy egy csekély létszámú remete közösség már a 13. század közepén élhetett a ma is látható monostor helyén, vagy annak közelében. Életüket, a közösség vagyonának gyarapodását nagylelkűen támogatta Nagy Lajos király, Luxemburgi Zsigmond és később Mátyás király is. A szentléleki kolostor elnéptelenedése, pusztulása a 16. század közepén történt. Az épületet a szerzetesek többé nem építették újjá.

A kolostor első tudományos igényű régészeti kutatását Czeglédy llona kezdte meg 1974-ben. A feltárásokat állagmegóvás is követte, melynek munkálatait Ferenczy Károly irányította. A helyreállítás főként a templom területét érintette, a kolostornégyszöget ekkor kitakarították, falait szárazon rakott kőfallal emelték ki. Az eltelt közel negyven évben sem a kolostor, sem a templom területén nem történt állagmegóvási munka, csupán a leszakadáshoz közel álló diadalív aládúcolását végezték el.

2012-ben az aládúcolás megszüntetését, a diadalív teljes helyreállítását célzó civil kezdeményezéshez kapcsolódóan kezdett a miskolci Herman Ottó Múzeum a kolostor területén kisebb régészeti kutatásba. Munkánkat a Bükki Nemzeti Park Igazgatósága mellett több önkéntes is segítette. Ebben az évben föleg a kolostornégyszög területén végeztük szondázó jellegú kutatásainkat. A feltárás eredményei alapján feltételezzük, hogy a kolostort három építési periódusban alakították ki. Az első, csekély alapterületű létesítményt a 14. század elején építették. Később, szintén a 14. században megtörtént a kolostor első átépítése, bővítése. Ma is látható formáját a 15. században nyerte el, ekkor közel 1 méterrel tették szélesebbé az épületet. A pálos kolostor első 
fázisát annak 14. század eleji létrehozásához köthetjük. A bővítéssel járó átépítést a 14. század közepén és végén kapott, nagyobb adományokból befolyó pénzösszegek tették lehetővé. A szentléleki kolostor épületének utolsó átépítését a 15. században juttatott javadalmak biztosították. Az ásatás befejezését követően a kerengőudvar és a kerengőfolyosó falainak ideiglenes állagvédelmét is - szintén civil összefogással - elvégeztük.

A szentléleki kolostor feltárását 2013-ban is folytatni szeretnénk, melynek alkalmával remélhetőleg több adatot nyerünk a szerzetesek életteréröl, az egyes helyiségek méretéröl és elhelyezkedéséről. Egyik célunk az, hogy a 2012-ben a nyugati traktusban előkerült helyiség kiterjedéséről, funkciójáról bővebb információkat szerezzünk.

\title{
The history of the Pauline friary near Miskolc and it's archeological excavation in $\mathbf{2 0 1 2}$
}

\author{
MELINDA MISKOLCZI - ANDRÁS GÁBOR SZÖRÉNYI
}

According to written sources the Pauline monastery of Szentlélek - its medieval name is Dédes - was established in the early 14th century. However, on the basis of earlier data of a document we may assume that a small anchoretic community lived on the today still visible place of the monastery or in its adjacencies. The life and the increase of the community's assets were generously supported by King Louis the Great, and later King Matthias. The depopulation and destruction of the monastery of Szentlélek happened in the middle of the 16th century. The building was not rebuilt by the monks.

The first scientific archaeological research of the monastery was started in 1974 by llona Czeglédy. The excavation was also followed by preservation, which was led by Károly Ferenczy. The reconstruction has mainly concerned the area of the church; the monastery square was cleaned up then, on its old walls dry stacked stone walls were built. In the following period of nearly forty years there has not been carried out any conservation work in the area of the monastery and the church. Only the buttressing of the chancel arch, which stood near to the abysm, was accomplished.

In connection with a civil society initiative (the abolition of the buttress and the complete restoration of the chancel arch) the Herman Otto Museum in Miskolc started a small archaeological research in the area of the monastery in 2012. Besides the help from the Bükk National Park Directorate we got help from several volunteers, too. During this year we performed test excavations mainly in the area of the monastery square. On the basis of the results of this excavation we assume that the monastery was built in three different periods. The first building, which had a small floor-space, was built at the beginning of the14th century. Later, also in the 14th century, the monastery was rebuilt and extended for the first time. The renovation and enlargements of the monastery were carried out in the mid to late 14th century. Money from major donations allowed this. Today you can still see the shape, which was achieved in the 15th century. At that time the building was broadened by almost 1 meter. The last renovation of the monastery of Szentlélek was ensured by benefaction during the 15th century.

After the completion of the excavation we performed a temporary conservation of the walls of the cloister and ambulatory with civilian collaboration, too.

We would like to continue the excavation of the monastery of Szentlélek in 2013, too. In doing so, we hope to get a lot of data about the living-space of the monks and the sizes and locations of the several rooms. One of our goals is to gain more information about the extent and function of the room found in the western wing in 2012.

\section{Irodalom}

Bodó B. 2010.: A szentléleki pálos kolostor. Várak, kastélyok, templomok VI/3. 12-15.

DL: Magyar Országos Levéltár Diplomatikai Gyüjtemény (www.arcanum.hu)

F. Romhányi Beatrix 2007.: Pálos gazdálkodás a 15-16. században. Századok 141/2. 299-351.

Hervay F. 1984.: A pálos rend elterjedése a középkori Magyarországon. In.: Mályusz Elemér emlékkönyv. Szerk.: H. Balázs Éva - Fügedi Erik - Maksay Ferenc, Budapest, 159-172.

HOM Rég. Ad.: A Herman Ottó Múzeum Régészeti adattára

Joó T. 1972.: Adalékok a sátoraljaújhelyi volt pálos-piarista templom, kolostor és berendezései történetéhez. Herman Ottó Múzeum Évkönyve 11. 145-188.

Joó T. - Sólyom D. 1973.: A diósgyőri pálos kolostor. Herman Ottó Múzeum Évkönyve 12. 87-120.

Kárpáti B. 2002:: Miskolci várostörténeti kalendárium (1300-1960). Borsod-Abaúj-Zemplén Megyei Levéltári Füzetek 39. Miskolc

Lovász E. 2004.: Diósgyőr és a majládi kolostor 700 éves története. Miskolc

Marjalaki Kiss L. 1987.: A szentléleki zárda legrégibb okleveles adata (Tardona határjárása 1240-ben). Történeti tanulmányok. Miskolc várostörténeti közlemények I. Miskolc, 45-48. 